\title{
Antibacterial Activity of Different Toothpastes on the Mouth's Microflora of Students of the Federal Polytechnic Ede, Osun State, Nigeria
}

\author{
Magdalene C. Igboama*, Bolaji A. Samuel, I.I. Olufade, Sustain K. Owonibi, \\ Israel A. Ogunsumi and J.E. Adamu \\ Department of Science Laboratory Technology, Federal Polytechnic Ede, Osun State, Nigeria \\ *Corresponding author
}

\section{Keywords}

Antibacterial activity, Bacterial isolates, Plaque samples, Floss, Active ingredients, Dental diseases

\section{Article Info}

Accepted:

28 May 2020

Available Online:

10 June 2020

\begin{abstract}
A B S T R A C T
Dental diseases are a major health concern in Nigeria. This study was designed to investigate the antibacterial activity of five different toothpastes on the bacterial isolates present in the mouth of students of the Federal Polytechnic Ede, Osun State. Thirty students of the institution were enrolled in this study. Plaque samples were collected from their teeth using floss and the following microorganisms were isolated from the samples; Streptococcus pyogenes, Streptococcus mutans, Streptococcus pneumoniae, Staphylococcus aureus, Staphylococcus epidermidis, Micrococcus luteus, Enterococcus faecalis and Acinetobacter baumanii. Antibacterial activity of each test toothpaste coded as Tb1 - Tb5 was tested against each identified bacterium using Agar well diffusion method. Varying degrees of antibacterial activity were displayed by each of the test toothpastes against all the bacteria isolated in this study. Test toothpastes Tb1 and Tb2 inhibited the growth of almost all the bacterial isolates except E. faecalis and A. baumanii respectively while two or more bacteria exhibited resistance against toothpaste brands $\mathrm{Tb} 3$, Tb4 and Tb5 with Tb3 demonstrating the least antibacterial activity. To achieve good oral health, there is need to balance up active ingredients to appropriate levels in all toothpastes so that in addition to providing protection against sensitivity, they can also protect the teeth from dental diseases caused by bacteria.
\end{abstract}

\section{Introduction}

Good oral health is a state of being free from oral infections, oral sores, chronic mouth pain, gum disease, tooth decay, tooth loss, and other oral disorders that limit an individual's capability in biting, chewing, smiling and speaking. Such limitations can affect the psychology and facial appearance of such an individual. Oral cavity has favorable physicochemical conditions like warmth and moistness for the growth of a diverse range of microorganisms including bacteria, archaea, mycoplasma, virus, protozoa, and fungi. Of them all, bacteria are the most numerous with over three hundred types in the mouth (Roberts, 2005). In individuals, bacteria colonize the tooth surface at the neck region and form dental biofilm popularly known as plaque which is a major cause of the 
development of dental caries which itself constitutes one of the most common dental diseases in different parts of the world (Narhi, et al., 1994; Benson et al., 2004; Williams and Cummins, 2003). The microbial community in Plaques are able to display pathogenic synergism and restrict the penetration of antimicrobial agents thus they need to be carefully brushed out with toothbrush and good toothpaste containing active ingredients or antibacterial agents in order to suppress growth of bacteria and prevent different kinds of dental diseases (Nwakanma et al., 2014; Prasanth, 2011).

The active ingredients in toothpastes vary among different types of toothpastes. Natural or herbal toothpastes are those without fluoride but with natural ingredient such as sodium chloride and plant extracts like lemon, rosemary, sage, chamomile, Echinacea, rhatany, peppermint and myrrh while Chemical based toothpastes contain abrasives, fluoride, anti-tartar agents, sodium bicarbonate, enzymes, to enhance the antibacterial properties of saliva, xylitol, a non-sugar sweetener, detergent among others. Herbal ingredients have several benefits; Chamomile has anti-inflammatory effect, Echinacea has immune stimulatory property, Sage and Rhatany have anti-hemorrhagic properties, Myrrh is a natural antiseptic and eliminates bad breath, Pepperminth oil has analgesic and anti-inflammatory properties while Rosemary is antiseptic (George and Bath,2008; Pourabbas et al., 2005; Prasanna et al., 2011). On the other hand, Fluoride in contemporary toothpastes strengthens teeth and prevents their deterioration by making the teeth more resistant to acid attacks from plaque bacteria and sugars in the mouth (Machiulskiene et al., 1998).

There is a wide array of toothpaste brands in different markets in Nigeria which are either of local/foreign origin or of herbal/chemical composition from which consumers make their choices based on different parameters such as prices, packaging, long-standing brand name among other things but not necessarily based on quality. This study was therefore designed to test the efficacy of some of the toothpaste brands (Herbal and chemical based) sold in local markets in Nigeria against dental caries bacteria.

\section{Materials and Methods}

All materials including media, glass wares and bench surfaces were adequately sterilized and five (5) unexpired brands of toothpastes coded as Tb1-Tb5 were purchased from a local market in Ede. Tb1 and $\mathrm{Tb} 2$ were herbal toothpastes while $\mathrm{Tb} 3, \mathrm{~Tb} 4$ and $\mathrm{Tb} 5$ were contemporary or chemical based toothpastes.

\section{Collection of samples}

A sterile swab was moistened with normal saline and was rubbed on the surface of the dental plaque of each of the twenty students. A new sterile swab was used for each student respectively. The samples were stored separately in new sterile polythene bags after which they were immediately transported to the laboratory for examination.

\section{Isolation of bacteria}

Each swab was inoculated unto sterile Nutrient agar, Mac-Conkey agar and blood agar prepared according to manufacturers' instruction. The plates were incubated at $37^{\circ} \mathrm{C}$ for 24 hours after which developed colonies were sub cultured. Pure cultures were stored in slants at $4 \mathrm{C}$.

\section{Characterization and identification of bacteria isolates}

The isolates were characterized and identified based on their cultural characteristics, grams stain and biochemical reactions. 
Antibacterial activity of test toothpastes on the identified bacteria isolates using agar well diffusion method

Broth culture of each test organism was prepared in peptone water and allowed to stand for eighteen hours. $0.1 \mathrm{ml}$ of the broth culture of each test organism was then added to $20 \mathrm{ml}$ sterile molten nutrient agar which had already cooled to $44^{\circ} \mathrm{C}$. The bottles were gently rotated to mix the inoculums with the media and these were then poured into properly labeled sterile petri-dishes. The seeded media were allowed to set and holes were bored on the seeded media using a sterile cork-borer. Stock solution of each test toothpaste was then prepared by dissolving $1.0 \mathrm{~g}$ of each test toothpaste in $2 \mathrm{mls}$ of sterile water contained in separate and appropriately labeled test tubes and $0.5 \mathrm{mls}$ of each stock solution was then pipetted from each test tube into the bored holes (wells). The plates were labeled appropriately and allowed to stand for one hour to enhance proper diffusion of the toothpaste into the seeded medium. They were then incubated at $35^{\circ} \mathrm{C}$ for 24 hours after which the clear zones of growth inhibition around the wells were measured and recorded in millimeter $(\mathrm{mm})$ respectively.

\section{Results and Discussion}

A total of eight (8) bacteria isolates were isolated from the dental samples of thirty (30) students of the Federal Polytechnic Ede, Osun state. Bacterial isolates identified were: Streptococcus pyogenes, Streptococcus mutans, Streptococcus pneumoniae, Staphylococcus aureus, Staphylococcus epidermidis, Micrococcus luteus, Enterococcus faecalis and Acinetobacter baumanii (Table 2).

Varying degrees of antibacterial activity were displayed by each of the test toothpastes against all the bacteria isolated in this study.
Compared to the other four toothpastes, Tb1 displayed the widest zones of inhibition against all the susceptible bacteria and inhibited the growth of all the bacteria isolates except for Enterococcus faecalis which was resistant to its effect after 24 hours. Tb2 was also observed to inhibit the growth of all the bacterial isolates except that of Acinetobacter baumannii. The inhibitory effect manifested by these two herbal toothpastes could be because they contain natural antibacterial agents which are more effective in killing bacteria than the ones in the regular tooth pastes (Tsyarini et al., 2003). Two of the isolates in this study, Enterococcus faecalis and Acinetobacter baumannii dispayed resistance to $\mathrm{Tb} 4$. Resistance was also observed by Enterococcus faecalis, Acinetobacter baumannii and Streptococcus epidermidis against $\mathrm{Tb} 5$. On the other hand, all the bacterial isolates in this study were resistant to $\mathrm{Tb} 3$ except Streptococcus pneumoniae and Staphylococcus aureus (Table 3).

The study revealed that four (4) out of the five (5) test toothpastes in this study exhibited good levels of effectiveness against the bacterial isolates as revealed by the effectiveness percentages in Table 4. The two natural/herbal toothpastes $\mathrm{Tb} 1$ and $\mathrm{Tb} 2$ displayed the highest effectiveness activity of $87.5 \%$ respectively. This is similar to the findings of Shweta et al., (2017) and could be attributed to the presence of herbal ingredients like Babool and Neem extracts in natural/herbal tooth pastes (Sharma et al., 2014) as these extracts have been shown to possess astringent and antiseptic activity (Lakshmi et al., 2015) and have also been shown to be very effective at treating and preventing dental infection (Bhambal et al., 2011). The study also revealed that the chemical toothpastes $\mathrm{Tb} 4$ and $\mathrm{Tb} 5$ exhibited effectiveness activity of $75.0 \%$ and $62.5 \%$ respectively while the lowest percentage of 
effectiveness activity of $25.0 \%$ was exhibited by the chemical toothpaste $\mathrm{Tb} 3$. These results correlate with the result of the work done by Subramonian et al., (2016). The low percentage of effectiveness activity of the tooth paste brand $\mathrm{Tb} 3$ could be attributed to the fact that $\mathrm{Tb} 3$ is mainly formulated to relieve the pain of sensitivity in teeth and as such may not contain the active ingredient fluoride in the right concentration as fluoride containing toothpastes have been found to be highly effective against oral acidogenic bacteria (Chadrabhan et al., 2012; Maripandi et al., 2011).

Over all, $\mathrm{Tb} 1$ and $\mathrm{Tb} 2$ are the most active of all the test toothpastes followed by $\mathrm{Tb} 4$ and $\mathrm{Tb} 5$ while $\mathrm{Tb} 3$ is the least active.

Table.1 Growth of isolates on different culture media

\begin{tabular}{|c|c|c|c|}
\hline Isolate Code & Nutrient agar & Blood agar & Mac-Conkey \\
\hline JA & $\begin{array}{l}\text { Bright yellow circular } \\
\text { colonies with regular edges }\end{array}$ & $\begin{array}{l}\text { Gamma } \\
\text { haemolysis }\end{array}$ & Growth \\
\hline JB & $\begin{array}{l}\text { Smooth cream colonies } \\
\text { with entire edges }\end{array}$ & $\begin{array}{l}\text { Gamma } \\
\text { haemolysis }\end{array}$ & No growth \\
\hline JC & $\begin{array}{l}\text { White smooth raised } \\
\text { circular colonies } \\
\text { entire margin }\end{array}$ & Beta haemolysis & No growth \\
\hline JD & $\begin{array}{l}\text { Light Yellow circular } \\
\text { colonies }\end{array}$ & Beta haemolysis & No growth \\
\hline $\mathbf{J E}$ & White colonies & $\begin{array}{l}\text { Gamma } \\
\text { haemolysis }\end{array}$ & No growth \\
\hline $\mathbf{J F}$ & Yellow colonies & Alfa haemolysis & No growth \\
\hline JG & Grey, mucoid colonies & Alfa haemolysis & No growth \\
\hline JH & $\begin{array}{l}\text { Smooth, pale yellow } \\
\text { colonies }\end{array}$ & Beta haemolysis & Growth \\
\hline
\end{tabular}


Table.2 Morphological and Biochemical Characterization of the Bacteria Isolates

\begin{tabular}{|c|c|c|c|c|c|c|c|c|c|c|c|c|c|c|c|c|c|c|c|c|c|}
\hline 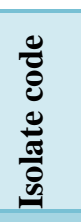 & $\begin{array}{l}\frac{\ddot{\Xi}}{\pi} \\
\frac{\pi}{\omega} \\
\overline{\bar{d}}\end{array}$ & 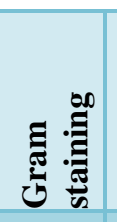 & 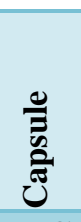 & के & 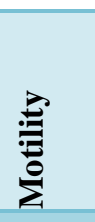 & 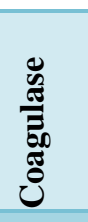 & 氖 & 苋 & 芯 & 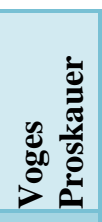 & $\begin{array}{l}\overrightarrow{\tilde{g}} \\
\stackrel{0}{0} \\
\frac{0}{0} \\
\underline{\Xi}\end{array}$ & 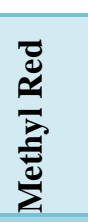 & 窇 & 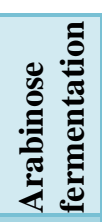 & 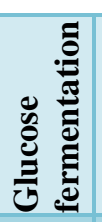 & r $\begin{array}{l} \\
\end{array}$ & 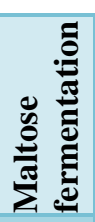 & 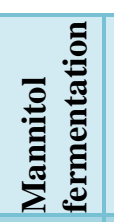 & 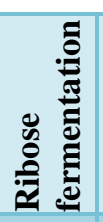 & 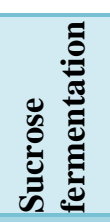 & 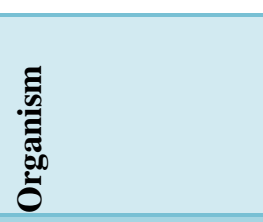 \\
\hline JA & Cocci & $+v e$ & $\mathrm{NC}$ & NS & NM & -ve & -ve & + ve & + ve & $-v e$ & -ve & -ve & $-v e$ & $-v e$ & $+\mathrm{ve}$ & $-\mathrm{ve}$ & - ve & + ve & $+\mathrm{ve}$ & - ve & M. luteus \\
\hline JB & Cocci & $+v e$ & $\mathrm{NC}$ & NS & NM & -ve & -ve & -ve & -ve & +ve & -ve & -ve & $+v e$ & -ve & +ve & $+v e$ & $+v e$ & $+v e$ & $+\mathrm{ve}$ & $+v e$ & E. faecalis \\
\hline $\mathrm{JC}$ & Cocci & $+v e$ & $\mathrm{NC}$ & NS & NM & $+v e$ & -ve & $+v e$ & $+v e$ & $+v e$ & -ve & $+v e$ & -ve & -ve & $+v e$ & $+v e$ & $+v e$ & $+v e$ & $+\mathrm{ve}$ & $+v e$ & S. aureus \\
\hline JD & Cocci & + ve & $\mathrm{C}$ & NS & NM & -ve & $+v e$ & -ve & -ve & -ve & -ve & -ve & -ve & -ve & $+\mathrm{ve}$ & $+v e$ & $+v e$ & -ve & -ve & $+v e$ & S. pyogenes \\
\hline JE & Cocci & +ve & $\mathrm{C}$ & NS & NM & -ve & -ve & +ve & +ve & +ve & -ve & +ve & +ve & -ve & +ve & + ve & +ve & -ve & +ve & +ve & S. epidermidis \\
\hline $\mathbf{J F}$ & Cocci & $+v e$ & $\mathrm{C}$ & NS & NM & -ve & $+v e$ & -ve & -ve & $+\mathrm{ve}$ & -ve & -ve & -ve & -ve & +ve & $+\mathrm{ve}$ & +ve & +ve & -ve & +ve & S. mutans \\
\hline JG & Cocci & +ve & $\mathrm{C}$ & NS & NM & -ve & +ve & -ve & -ve & -ve & -ve & -ve & -ve & $+v e$ & $+v e$ & $+\mathrm{ve}$ & $+v e$ & -ve & -ve & $+v e$ & S. pneumoniae \\
\hline JH & $\begin{array}{l}\text { Cocco- } \\
\text { bacilli }\end{array}$ & -ve & $\mathrm{C}$ & NS & NM & & $+\mathrm{ve}$ & $+\mathrm{ve}$ & + ve & -ve & -ve & -ve & +ve & -ve & $+\mathrm{ve}$ & -ve & -ve & $-\mathrm{ve}$ & $-v e$ & -ve & A. baumannii \\
\hline
\end{tabular}

KEY C -Capsulated,

NC -Non capsuated, NS- Non sporing, M- motile, NM - Non motile, +ve -Positive, -ve -Negative

Table.3 Zone of inhibition of the test organisms after 24 Hours

\begin{tabular}{|l|l|l|l|l|l|}
\hline Test organism & Tb1 & Tb2 & Tb3 & Tb4 & Tb5 \\
\hline Streptococcus pyogenes & 31.0 & 28.0 & 0.0 & 27.0 & 24.0 \\
\hline Streptococcus mutans & 33.0 & 32.0 & 0.0 & 30.0 & 21.0 \\
\hline Streptococcus pneumoniae & 22.0 & 20.0 & 10.0 & 20.0 & 12.0 \\
\hline Staphylococcus aureus & 25.0 & 22.0 & 11.0 & 23.0 & 14.0 \\
\hline Staphylococcus epidermidis & 16.0 & 14.0 & 0.0 & 15.0 & 0.0 \\
\hline Micrococcus luteus & 30.0 & 27.0 & 0.0 & 27.0 & 10.0 \\
\hline Enterococcus faecalis & 00.0 & 10.0 & 0.0 & 0.0 & 0.0 \\
\hline Acinetobacter baumannii & 11.0 & 0.0 & 0.0 & 0.0 & 0.0 \\
\hline
\end{tabular}

KEY Tb1-Tb5: Toothpaste brand 1- Toothpaste brand 5 
Table.4 Percentage effectiveness activity of test toothpastes on all the bacterial isolates

\begin{tabular}{|c|c|}
\hline Test toothpastes & Effectiveness activity (\%) \\
\hline Tb1 & 87.5 \\
Tb2 & 87.5 \\
Tb3 & 25.0 \\
Tb4 & 75.0 \\
Tb5 & 62.5 \\
\hline
\end{tabular}

Conclusion and recommendation are as follows:

At the end of the study, toothpaste brands $\mathrm{Tb} 1, \mathrm{~Tb} 2, \mathrm{~Tb} 4$ and $\mathrm{Tb} 5$ showed good antibacterial activity but the two herbal toothpastes were more effective as they inhibited the growth of most of the isolated bacteria in this study. Thus most toothpastes purchased from the markets in Nigeria have good antibacterial quality however, there is need to add a more effective and safe antibacterial ingredient to toothpastes in order to boost their antibacterial action for better dental health. In addition, manufacturers of pain relief toothpastes for sensitive teeth should incorporate required amounts of fluoride into their products in order to achieve dual purpose of relieving pain in sensitive teeth and inhibiting growth of dental bacteria.

\section{References}

Benson P.E., Douglas C.W. and Martin M.N. (2004): Flouridated elsomers: Effects on the Microbiology of plaque. AMJ. Orthod. Dento facial Orthop. Pp 325330.

Bhambal A, Kothari A.S, Saxena S., Jain M (2011). Comparative effect of Neemstick and Toothbrush on plaque removal and gingival health - A Clinical trial. Journal Adv. Oral Res; 2:51-6.

Chandrabhan Dhrum, Hemlata Rajmani, Renu Bhatt and Pradeep Verma (2012): Isolation of Dental Caries Bacteria from
Dental plaque and Effect of Toothpastes on Acidogenic Bacteria. Open Journal of Medical Microbiology Vol 2 (3) Id. 22816. Doi: 10.4236/ojmm. 65.

George D. Bath S.S., Anatomy B. (2008): Comparative evaluation of the antimicrobial efficacy of Aloe vera tooth gel and two popular

commercial toothpastes: An in vitro study. General Dentistry.: 238: 40.

Lakshmi T., Vidya Krishnan, Rajendran R., Madhusudhanan N. (2015) Azadirachta indica: A herbal panacea in dentistry An Update Pharmacogn Rev. 9(17): 4144.

Machiulskiene V., Nyvadi B., Baelum V. (1998). Prevalence and Severity of Dental Carries in 12- year old children in Kaunas, Lithuania 1995. Carries Res. 32(3) 175-180.

Maripandi A., Kumar T.A., AlSalamah A.A. (2011): Prevalence of dental caries bacterial pathogens and evaluation of inhibitory concentration effect of different toothpastes against Streptococcus spp. African Journal of Microbiology Research.; 5(14): 17781783.

Nwakanma C., Ejim C.J. and Unachukwu M.N. (2014): The Effect of Selected Toothpaste on the Microbial flora of the Mouth of G.O.U.

Narhi T, Ainamo A, and Meurman J. (2011): Mutans Streptococci and Lactobacilli in the elderly. Scand. J. Dent. Res., 102, 97. 
Pourabbas R., Delazer A., Chitsaz M.T. (2005): The effect of German chamomile mouthwash on dental plaque and gingival inflammation. Iranian journal of Pharmaceutical Research. 2:105-9.

Prasanna Neelakantan, Nithya Jagannathan, Nabeel Nazar. (2011): Ethnopharmacological approach in Endodontic Treatment: A Focused

Review. International Journal of Drug Development and Research. 3(4):68-77.

Prasanth M. (2011): Antimicrobial Efficacy of Different Toothpaste and Mouthrinses: An in vitro study, Dent. Res. J. 8(2), 85.

Roberts A. (2005): Bacteria in the mouth. Dent Update. Pp 134-136, 139-140, 142.

Sharma Abhishek, Bharat Sankhla, Suja M Parkar, Sudheer Hongal, Thanveer K, Ajithkrishnan C.G: (2014): Effect of Traditionally Used Neem and Babool Chewing Stick (Datun) on Streptococcus mutans: An in vitro Study Journal of Clinical and Diagnostic Research, 8(7): ZCI5-ZCI7.
Shweta Sao, Shishir and Antu Kurrey (2017): The study of Effectiveness and Resistance of Various Toothpaste on Mouth Microbial Flora. World journal of Pharmaceutical Research. www.wjpr.net 6(8).

Subramonian S., Segin C., Murugan M., Murugan T. (2016): Assessment of antimicrobial efficacy of different toothpaste on dental caries bacteria. International Journal of Pharmaceutical and Clinical Research, 8(6), 548.

Tsyarini E, Rusmana D, Widya (2003): Comparison of the Effectiveness of Herbal Toothpaste and Nonherbal Toothpaste in Inhibiting the Growth of Staphylococcus aureus, Streptococcus $\beta$-hemoliticus and Candida albicans in vitro. [In Indonesia]. [Thesis]. Faculty of Dentistry, Universitas Maran1atha; $p$. 1-27.

Williams M. L and Cummins D. (2003): The technology behind Close-Up Total Advanced Fresh. Compend Continue Education : Dent, 24: 4-9.

\section{How to cite this article:}

Magdalene C. Igboama, Bolaji A. Samuel, I.I. Olufade, Sustain K. Owonibi, Israel A. Ogunsumi and Adamu, J.E. 2020. Antibacterial Activity of Different Toothpastes on the Mouth's Microflora of Students of the Federal Polytechnic Ede, Osun State, Nigeria. Int.J.Curr.Microbiol.App.Sci. 9(06): 4101-4107. doi: https://doi.org/10.20546/ijcmas.2020.906.481 